\title{
Effect of Spices on Biofilm Forming Capacity of Bacteria
}

\author{
S. Esra Buyukcombak, Arnela Fazlić, \\ Sabahudin Ćordić, \\ Genetics and Bioengineering, \\ International Burch University, \\ Sarajevo, Bosnia and Herzegovina
}

\author{
Mirsada Hukić, \\ Institute for Biomedical Diagnostics and Research \\ NALAZ \\ Academy of Sciences and Arts \\ Bosnia and Herzegovina
}

\author{
Monia Avdić \\ Genetics and Bioengineering, \\ International Burch University, \\ Sarajevo, Bosnia and Herzegovina
}

\begin{abstract}
Spices, which are plant substances used to enhance flavor are at the same time, the most commonly used natural antimicrobial agents in food. Besides this they have shown to effect the biofilm forming capacity of bacteria at different concentrations. In our study we tested the antibacterial effect of different $w / V$ solutions of commercially available spices: cinnamon, curcuma and ginger and investigated their effect on biofilm formation of Staphylococcus aureus ATCC 25923, Escherichia coli ATCC 25922 and Enterococcus faecalis ATCC 19433. The results of our study indicate that cinnamon had an antibacterial effect on gram positive bacteria, ginger only on E.coli and curcuma did not exhibit any antibacterial properties. Results of the effect of different w/V solutions of spices on biofilm formation of the tested bacteria indicate that the spices had different effects on the tested bacteria and that the applied spice w/V solution did modify biofilm formation of bacteria. Hereby it is evident that the finding of novel antimicrobial compounds should be accompanied by biofilm formation studies since biofilms represent the natural state of bacteria and as such must be taken into consideration.
\end{abstract}

\section{Keywords-Spices, Antimicrobial Effect, Antibiofilm Effect}

\section{INTRODUCTION}

Biofilms are sessile communities of micro-organisms where microbes are embedded in an extracellular polymeric substance [1] and as such show elevated resistance rates to antibiotics and antimicrobials [2, 3, 4]. Nearly all $(99.9 \%)$ micro-organisms have the ability to form biofilms on a wide range of biological and nonbiological surfaces [1]. Due to their elevated resistance rates towards antimicrobials [2, 3, 4] and the fact that antibiotics can act as signaling molecules and effect biofilm formation $[6,7,8,9]$, today biofilms represent a major problem in public health, medicine, industry and everyday life [3, 4].

Due to the inducing effect some antibiotics have on biofilm formation, many studies were directed towards investigating the antimicrobial and antibiofilm effect of different natural substances $[10,11,12,13,14]$ to solve this issue. The existence of many small molecules within natural substances makes them good candidates as quorum quenching molecules in biofilm studies.

Since biofilms have a profound influence in the food industry $[15,16,17]$ the effect of commonly used spices on biofilm forming capacity of microbes is of great significance. Spices, which are plant substances used to enhance flavor [18] are at the same time, the most commonly used natural antimicrobial agents in food [5].

Ginger, a famous spice used in the regular diet in many Asian countries, consists of more than 400 different compounds. Many studies confirmed its antimicrobial and antibiofilm properties [19, 20, 21, 22].

Cinnamon, a spice commonly used in culinary and a health promoting agent for many diseases [23, 24, 25,] has also been confirmed as a antimicrobial and antibiofilm agent [26, 27, 28].

Curcumin, the major constituent of Curcuma longa L. possess a broad range of pharmacological properties including antimicrobial, antidiabetic, anti-inflammatory, anticancer, and antioxidant effect [29, 30, 31]. Its antibiofilms forming effect was also confirmed on some bacteria [30] while in the case of K.pneumoniae it had no antibiofilm effect [32].

The main aim of our study was to test the antimicrobial effect of three commonly used commercially available spices and the effect these spices have on biofilm formation of referent strains of the following pathogenic microorganisms found in food: Staphylococcus aureus, Escherichia coli and Enetrococcus faecalis.

\section{MATERIALS AND METHODS}

\section{A. Bacterial Strains}

The tested organisms included cultures of: Staphylococcus aureus ATCC 25923, Escherichia coli ATCC 25922 and Enterococcus faecalis ATCC 19433 in Lauria Bertani (LB) Broth supplemented with $50 \%$ glycerol and kept at $-80^{\circ} \mathrm{C}$. These bacterial strains were recovered from glycerol stocks by plating on Blood Agar Base and incubated overnight at $37^{\circ} \mathrm{C}$ followed by overnight incubation in Tryptic soy broth (TSB) supplemented with $1 \%$ glucose.

\section{B. Source of Spices}

The used spices included commercially available Ginger, Cinnamon and Curcumin. The used spices were aseptically diluted in TSB supplemented with $1 \%$ glucose in the following (w/V) solutions: $75 \%, 50 \%, 25 \%$.

The $25 \%(\mathrm{w} / \mathrm{V})$ solutions were further used for the creation of the following serial dilutions: $25 \%, 12,5 \%, 6,25 \%, 3,125 \%$, $1,56 \%, 0,78 \%, 0,39 \%, 0,195 \%, 0,098 \%$. 


\section{Antibacterial Testing}

The antibacterial testing of the tested spices (ginger, cinnamon, curcumin) was performed using agar well method on Mueller Hinton Agar for the following (w/V) solutions: $75 \%, 50 \%$ and $25 \%$. Zones of inhibition after overnight incubation were recorded in $\mathrm{mm}$.

\section{Biofilm Inhibition Efficiency of Spices}

The effect of ginger, cinnamon and curcumin were tested to determine their effect on biofilm forming capacity of the tested bacteria. Different w/V solutions of the tested spices were added to TSB in 96 well plates inoculated with the desired bacterial suspension to a density of McFarland 0.5 where the absorbance was quantified spectrophotometrically at $595 \mathrm{~nm}$. After $48 \mathrm{~h}$ incubation at $37^{\circ} \mathrm{C}$ the plates were stained with $0.1 \%$ crystal violet.

Uninoculated media was used as negative control and bacteria in TSB as positive control.

\section{E. Examination of Biofilm Forming Capacity}

The biofilm formation was classified as strong, moderate, weak or non-adherent according to predefined formulas using the cut-off OD (ODc) (Table 1).

TABLE I. CUT OFF OD VALUES (AT 595 NM) AND CLASSIFICATION OF BACTERIAL ADHERENCE BY SPECTROPHOTOMETRIC ASSAY.

\begin{tabular}{|l|l|}
\hline \multicolumn{1}{|c|}{ Formula } & \multicolumn{1}{c|}{ Biofilm Formation } \\
\hline $\mathrm{OD} \leq \mathrm{ODc}$ & Not adherent \\
\hline $\mathrm{ODc}<\mathrm{OD} \leq 2 \times$ ODc & Weak \\
\hline $2 \times$ ODc $<\mathrm{OD} \leq 4 \times$ ODc & Moderate \\
\hline $4 \times$ ODc $<$ OD & Strong \\
\hline
\end{tabular}

\section{F. Statistical Analysis}

All experiments were carried out in triplicates and the data were obtained by ANOVA. The statistical analysis was carried out in IBM SPSS.

\section{RESULTS}

\section{A. Antibacterial Effect of Different Spice $w / V$ solutions on Bacteria}

The results of the effect of different spice w/V solutions on the three tested referent bacterial strains is shown in table 2 . Cinnamon had an antibacterial effect on E. faecalis and S.aureus, where the highest zone of inhibition for $E$. faecalis and S.aureus was recorded at the $50 \%$ w/V solution. Ginger had an antibacterial effect only on gram negative $E$. coli, while no zones of inhibition were recorded for E. faecalis and $S$. aureus. The highest zone of inhibition around $E$. coli appeared around the ginger $75 \% \mathrm{w} / \mathrm{V}$ solution. Curcuma did not have any antibacterial effect on all the tested bacterial strains.
TABLE II. EFFECT OF DIFFERENT SPICE W/V SOLUTIONS ON TESTED REFERENT BACTERIAL

\begin{tabular}{|l|l|l|l|l|}
\multicolumn{5}{c}{ STRAINS } \\
\hline \multirow{3}{*}{ Spice } & $\begin{array}{c}\text { w/V } \\
\text { solution }\end{array}$ & \multicolumn{1}{|c|}{ E.coli } & E.faecalis & \multicolumn{1}{|c|}{ S.aureus } \\
\cline { 2 - 5 } & \multicolumn{5}{|c|}{ Zon Inhibition } \\
\hline Cinnamon & $75 \%$ & 0 & $1,7 \mathrm{~mm}$ & $2,0 \mathrm{~mm}$ \\
\hline & $50 \%$ & 0 & $2,1 \mathrm{~mm}$ & $2,1 \mathrm{~mm}$ \\
\hline & $25 \%$ & 0 & 0 & 0 \\
\hline Ginger & $75 \%$ & $4,0 \mathrm{~mm}$ & 0 & 0 \\
\hline & $50 \%$ & $3,5 \mathrm{~mm}$ & 0 & 0 \\
\hline & $25 \%$ & 0 & 0 & 0 \\
\hline Curcuma & $75 \%$ & 0 & 0 & 0 \\
\hline & $50 \%$ & 0 & 0 & 0 \\
\hline & $25 \%$ & 0 & 0 & 0 \\
\hline
\end{tabular}

Since the $25 \% \mathrm{w} / \mathrm{V}$ solution for all the tested spices was not inhibitory for bacterial growth, serial dilutions for further testing were made from it.

\section{B. Effect of Different Spice $w / V$ solutions on Biofilm Forming Capacity of Bacteria}

1) Effect of Different $w / V$ solutions of Cinnamon on Biofilm formation of E.coli, E.faecalis and S.aureus

The calculated ODc for cinnamon in the case of E.coli was 0,0929 , for $E$. faecalis 0,0853 , and for $S$.aureus 0,0867 . For E.coli a change in biofilm category, compared to the positive control, was registered at the $25 \%, 12,5 \%$ and $6,25 \mathrm{w} / \mathrm{V}$ cinnamon solution. In the case of E. faecalis, a change in category occurred at the following w/V cinnamon solutions: from $25 \%$ to $1,56 \%$. In the case of $S$. aureus w/V cinnamon solution caused changes in biofilm formation ranging in category from weak to strong compared to the positive control (Table III).

TABLE III. EFFECT OF DIFFERENT V/W SOLUTIONS OF CINNAMON ON BIOFILM FORMATION OF E.COLI, E.FAECALIS AND S.AUREUS.

\begin{tabular}{|c|c|c|c|c|c|c|}
\hline \multirow{2}{*}{ 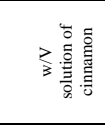 } & \multicolumn{2}{|c|}{ Escherichia coli } & \multicolumn{2}{|c|}{$\begin{array}{l}\text { Enterococcus } \\
\text { faecalis }\end{array}$} & \multicolumn{2}{|c|}{$\begin{array}{c}\text { Staphylococcus } \\
\text { aureus }\end{array}$} \\
\hline & $\begin{array}{c}\text { Mean } \\
\text { Abs. }\end{array}$ & Biofilm & $\begin{array}{l}\text { Mean } \\
\text { Abs. }\end{array}$ & Biofilm & $\begin{array}{l}\text { Mean } \\
\text { Abs. }\end{array}$ & Biofilm \\
\hline $\begin{array}{l}(-) \\
\text { Control }\end{array}$ & 0,0640 & $\begin{array}{l}\text { Non } \\
\text { adherent }\end{array}$ & 0,0593 & $\begin{array}{l}\text { Non } \\
\text { adherent }\end{array}$ & 0,0778 & $\begin{array}{l}\text { Non } \\
\text { adherent }\end{array}$ \\
\hline $\begin{array}{l}(+) \\
\text { Control }\end{array}$ & 0,0698 & $\begin{array}{l}\text { Non } \\
\text { adherent }\end{array}$ & 0,0665 & $\begin{array}{l}\text { Non } \\
\text { adherent }\end{array}$ & 0,3175 & Moderate \\
\hline $\begin{array}{l}\text { Only } \\
\text { spice }\end{array}$ & 0,0745 & $\begin{array}{l}\text { Non } \\
\text { adherent }\end{array}$ & 0,0745 & $\begin{array}{l}\text { Non } \\
\text { adherent }\end{array}$ & 0,0908 & Weak \\
\hline $0,098 \%$ & 0,0658 & $\begin{array}{l}\text { Non } \\
\text { adherent }\end{array}$ & 0,0808 & $\begin{array}{l}\text { Non } \\
\text { adherent }\end{array}$ & 0,1035 & Weak \\
\hline $0,195 \%$ & 0,0660 & $\begin{array}{l}\text { Non } \\
\text { adherent }\end{array}$ & 0,0795 & $\begin{array}{l}\text { Non } \\
\text { adherent }\end{array}$ & 0,2720 & Moderate \\
\hline $0,390 \%$ & 0,0670 & $\begin{array}{l}\text { Non } \\
\text { adherent }\end{array}$ & 0,0808 & $\begin{array}{l}\text { Non } \\
\text { adherent }\end{array}$ & 0,2275 & Moderate \\
\hline $0,780 \%$ & 0,0770 & $\begin{array}{l}\begin{array}{l}\text { Non } \\
\text { adherent }\end{array} \\
\end{array}$ & 0,0783 & $\begin{array}{l}\text { Non } \\
\text { adherent }\end{array}$ & 0,1960 & Moderate \\
\hline $1,560 \%$ & 0,1180 & $\begin{array}{l}\begin{array}{l}\text { Non } \\
\text { adherent }\end{array} \\
\end{array}$ & 0,0878 & Weak & 0,1928 & Moderate \\
\hline $3,125 \%$ & 0,1015 & $\begin{array}{l}\text { Non } \\
\text { adherent }\end{array}$ & 0,0950 & Weak & 0,3180 & Moderate \\
\hline $6,25 \%$ & 0,2343 & Moderate & 0,1135 & Weak & 0,5968 & Strong \\
\hline $12,5 \%$ & 0,2028 & Moderate & 0,2663 & Moderate & 0,4950 & Strong \\
\hline $25 \%$ & 0,4350 & Strong & 0,2863 & Moderate & 0,2080 & Moderate \\
\hline
\end{tabular}


2) Effect of Different $w / V$ solutions of Curcuma on Biofilm formation of E.coli, E.faecalis and S.aureus

The calculated ODc for cinnamon in the case of E. coli was 0.0843 , for $E$. faecalis 0,0853 and for $S$. aureus 0,0920 . Curcuma had no effect on biofilm formation in E.coli. A change in biofilm forming category was registered for $E$. faecalis at the w/V curcuma solution of $6,25 \%, 1,56 \%, 0,78 \%$ and $0,39 \%$. In the case of $S$. aureus curcuma had a inhibitory effect on biofilm formation (Table IV).

TABLE IV. EFFECT OF DIFFERENT V/W SOLUTIONS OF CURCUMA ON BIOFILM FORMATION OF E.COLI, E.FAECALIS AND

\begin{tabular}{|c|c|c|c|c|c|c|}
\hline \multicolumn{7}{|c|}{$\begin{array}{r}\text { S.AUREUS } \\
\end{array}$} \\
\hline \multirow{2}{*}{ 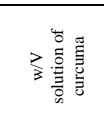 } & \multicolumn{2}{|c|}{ Escherichia coli } & \multicolumn{2}{|c|}{$\begin{array}{l}\text { Enterococcus } \\
\text { faecalis }\end{array}$} & \multicolumn{2}{|c|}{$\begin{array}{l}\text { Staphylococcus } \\
\text { aureus }\end{array}$} \\
\hline & $\begin{array}{l}\text { Mean } \\
\text { Abs. }\end{array}$ & Biofilm & $\begin{array}{l}\text { Mean } \\
\text { Abs. }\end{array}$ & Biofilm & $\begin{array}{l}\text { Mean } \\
\text { Abs. }\end{array}$ & Biofilm \\
\hline $\begin{array}{l}(-) \\
\text { Control } \\
\end{array}$ & 0,0593 & $\begin{array}{l}\begin{array}{l}\text { Non } \\
\text { adherent }\end{array} \\
\end{array}$ & 0,0593 & $\begin{array}{l}\begin{array}{l}\text { Non } \\
\text { adherent }\end{array} \\
\end{array}$ & 0,0783 & $\begin{array}{l}\text { Non } \\
\text { adherent }\end{array}$ \\
\hline $\begin{array}{l}+) \\
\text { Control }\end{array}$ & 0,0658 & $\begin{array}{l}\begin{array}{l}\text { Non } \\
\text { adherent }\end{array} \\
\end{array}$ & 0,0650 & $\begin{array}{l}\begin{array}{l}\text { Non } \\
\text { adherent }\end{array} \\
\end{array}$ & 0,3750 & Moderate \\
\hline $\begin{array}{l}\text { Only } \\
\text { spice }\end{array}$ & 0,0700 & $\begin{array}{l}\text { Non } \\
\text { adherent }\end{array}$ & 0,0685 & $\begin{array}{l}\text { Non } \\
\text { adherent }\end{array}$ & 0,1310 & Weak \\
\hline $0,098 \%$ & 0,0610 & $\begin{array}{l}\begin{array}{l}\text { Non } \\
\text { adherent }\end{array} \\
\end{array}$ & 0,0675 & $\begin{array}{l}\begin{array}{l}\text { Non } \\
\text { adherent }\end{array} \\
\end{array}$ & 0,1293 & Weak \\
\hline $0,195 \%$ & 0,0625 & $\begin{array}{l}\text { Non } \\
\text { adherent }\end{array}$ & 0,0693 & $\begin{array}{l}\text { Non } \\
\text { adherent }\end{array}$ & 0,1000 & Weak \\
\hline $0,390 \%$ & 0,0653 & $\begin{array}{l}\text { Non } \\
\text { adherent }\end{array}$ & 0,1870 & Weak & 0,1178 & Weak \\
\hline $0,780 \%$ & 0,0638 & $\begin{array}{l}\text { Non } \\
\text { adherent }\end{array}$ & 0,1193 & Weak & 0,0933 & Weak \\
\hline $1,560 \%$ & 0,0635 & $\begin{array}{l}\text { Non } \\
\text { adherent }\end{array}$ & 0,1388 & Weak & 0,0920 & Weak \\
\hline $3,125 \%$ & 0,0680 & $\begin{array}{l}\text { Non } \\
\text { adherent }\end{array}$ & 0,0773 & $\begin{array}{l}\text { Non } \\
\text { adherent }\end{array}$ & 0,0918 & $\begin{array}{l}\begin{array}{l}\text { Non } \\
\text { adherent }\end{array} \\
\text { ant }\end{array}$ \\
\hline $6,25 \%$ & 0,0627 & $\begin{array}{l}\text { Non } \\
\text { adherent }\end{array}$ & 0,1785 & Weak & 0,1003 & Weak \\
\hline $12,5 \%$ & 0,0660 & $\begin{array}{l}\text { Non } \\
\text { adherent }\end{array}$ & 0,0678 & $\begin{array}{l}\text { Non } \\
\text { adherent }\end{array}$ & 0,0930 & Weak \\
\hline $25 \%$ & 0,0763 & $\begin{array}{l}\text { Non } \\
\text { adherent }\end{array}$ & 0,0730 & $\begin{array}{l}\text { Non } \\
\text { adherent }\end{array}$ & 0,1073 & Weak \\
\hline
\end{tabular}

1) Effect of Different $w / V$ solutions of Ginger on Biofilm formation of E.coli, E.faecalis and S.aureus

The calculated ODc for ginger in the case of $E$. coli was 0.0902 , for E. faecalis 0,0853 and for $S$. aureus 0,0731 . Ginger caused no change in biofilm forming category of E.coli for all tested solutions. For E.facelis a change in biofilm forming category was registered at the w/V ginger solutions ranging from $25 \%-0,39 \%$. Most w/V ginger solutions had an inhibitory effect on biofilm formation of S.aureus (Table V).

TABLE V. EFFECT OF DIFFERENT V/W SOLUTIONS OF GINGER ON BIOFILM FORMATION OF E.COLI, E.FAECALIS AND S.AUREUS

\begin{tabular}{|c|c|c|c|c|c|c|}
\hline \multirow{2}{*}{ 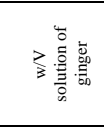 } & \multicolumn{2}{|c|}{ Escherichia coli } & \multicolumn{2}{|c|}{$\begin{array}{c}\text { Enterococcus } \\
\text { faecalis }\end{array}$} & \multicolumn{2}{|c|}{$\begin{array}{c}\text { Staphylococcus } \\
\text { aureus }\end{array}$} \\
\hline & $\begin{array}{l}\text { Mean } \\
\text { Abs. }\end{array}$ & Biofilm & $\begin{array}{l}\text { Mean } \\
\text { Abs. }\end{array}$ & Biofilm & $\begin{array}{l}\text { Mean } \\
\text { Abs. }\end{array}$ & Biofilm \\
\hline $\begin{array}{l}(-) \\
\text { Control } \\
\end{array}$ & 0,0618 & $\begin{array}{l}\text { Non } \\
\text { adherent }\end{array}$ & 0,0615 & $\begin{array}{l}\text { Non } \\
\text { adherent }\end{array}$ & 0,0730 & $\begin{array}{l}\text { Non } \\
\text { adherent }\end{array}$ \\
\hline $\begin{array}{l}(+) \\
\text { Control }\end{array}$ & 0,0638 & $\begin{array}{l}\text { Non } \\
\text { adherent }\end{array}$ & 0,0718 & $\begin{array}{l}\text { Non } \\
\text { adherent }\end{array}$ & 0,2735 & Moderate \\
\hline $\begin{array}{l}\text { Only } \\
\text { spice }\end{array}$ & 0,1228 & Weak & 0,0720 & $\begin{array}{l}\text { Non } \\
\text { adherent }\end{array}$ & 0,1235 & $\begin{array}{l}\text { Non } \\
\text { adherent }\end{array}$ \\
\hline $0,098 \%$ & 0,0653 & $\begin{array}{l}\text { Non } \\
\text { adherent }\end{array}$ & 0,0875 & Weak & 0,3573 & Moderate \\
\hline $0,195 \%$ & 0,0700 & $\begin{array}{l}\begin{array}{l}\text { Non } \\
\text { adherent }\end{array} \\
\end{array}$ & 0,0715 & $\begin{array}{l}\begin{array}{l}\text { Non } \\
\text { adherent }\end{array} \\
\end{array}$ & 0,1618 & Moderate \\
\hline $0,390 \%$ & 0,0655 & $\begin{array}{l}\text { Non } \\
\text { adherent }\end{array}$ & 0,0873 & Weak & 0,2103 & Weak \\
\hline $0,780 \%$ & 0,0685 & $\begin{array}{l}\begin{array}{l}\text { Non } \\
\text { adherent }\end{array} \\
\end{array}$ & 0,0738 & Weak & 0,0603 & $\begin{array}{l}\begin{array}{l}\text { Non } \\
\text { adherent }\end{array} \\
\end{array}$ \\
\hline $1,560 \%$ & 0,0670 & $\begin{array}{l}\text { Non } \\
\text { adherent }\end{array}$ & 0,1180 & Weak & 0,0825 & $\begin{array}{l}\begin{array}{l}\text { Non } \\
\text { adherent }\end{array} \\
\end{array}$ \\
\hline
\end{tabular}

\begin{tabular}{|l|l|l|l|l|l|l|}
\hline $3,125 \%$ & 0,0698 & $\begin{array}{l}\text { Non } \\
\text { adherent }\end{array}$ & 0,0870 & Weak & 0,0733 & $\begin{array}{l}\text { Non } \\
\text { adherent }\end{array}$ \\
\hline $6,25 \%$ & 0,0700 & $\begin{array}{l}\text { Non } \\
\text { adherent }\end{array}$ & 0,1245 & Weak & 0,0865 & $\begin{array}{l}\text { Non } \\
\text { adherent }\end{array}$ \\
\hline $12,5 \%$ & 0,0555 & $\begin{array}{l}\text { Non } \\
\text { adherent }\end{array}$ & 0,0815 & Weak & 0,0755 & $\begin{array}{l}\text { Non } \\
\text { adherent }\end{array}$ \\
\hline $25 \%$ & 0,0840 & $\begin{array}{l}\text { Non } \\
\text { adherent }\end{array}$ & 0,1105 & Weak & 0,0973 & $\begin{array}{l}\text { Non } \\
\text { adherent }\end{array}$ \\
\hline
\end{tabular}

\section{General Comparison of All Results}

1) Comparison of the Effect of Different Spices on S.aureus

$S$. aureus in the presence of ginger expressed the highest biofilm forming capacity at the $0,0975 \% \mathrm{w} / \mathrm{V}$ solution and the lowest biofilm forming capacity was measured at the $0,78 \%$ w/V solution. In the presence of cinnamon $S$. aureus expressed the highest biofilm forming capacity at the $6,25 \% \mathrm{w} / \mathrm{V}$ solution and the lowest biofilm forming capacity was measured at the $0,0975 \% \mathrm{w} / \mathrm{V}$ solution. S. aureus in the presence of curcuma expressed the highest biofilm forming capacity at the $0,0975 \% \mathrm{w} / \mathrm{V}$ solution and the lowest biofilm forming capacity was measured at the $3,125 \% \mathrm{w} / \mathrm{V}$ solution.

Fig. 1. Comparison of the effect of different spices on biofilm formtion of S.aureus ATCC 25923

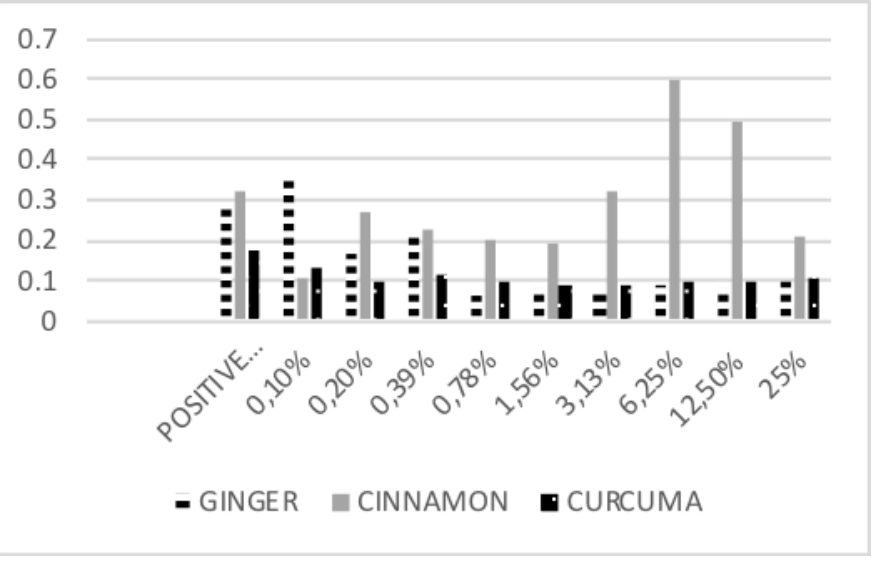

2) Comparison of the Effect of Different Spices on E.coli

$D$. coli in the presence of ginger expressed the highest biofilm forming capacity at the $25 \% \mathrm{w} / \mathrm{V}$ solution and the lowest biofilm forming capacity was measured at the $12,5 \% \mathrm{w} / \mathrm{V}$ solution. In the presence of cinnamon E. coli expressed the highest biofilm forming capacity at the $25 \% \mathrm{w} / \mathrm{V}$ solution and the lowest biofilm forming capacity was measured at the $0,0975 \% \mathrm{w} / \mathrm{V}$ solution. E. coli in the presence of curcuma expressed the highest biofilm forming capacity at the $25 \%$ w/V solution and the lowest biofilm forming capacity was measured at the $0,0975 \%$ w/V solution. 
Fig. 2. Comparison of the Effect of Different Spices on biofilm formation of E.coli ATCC 25922

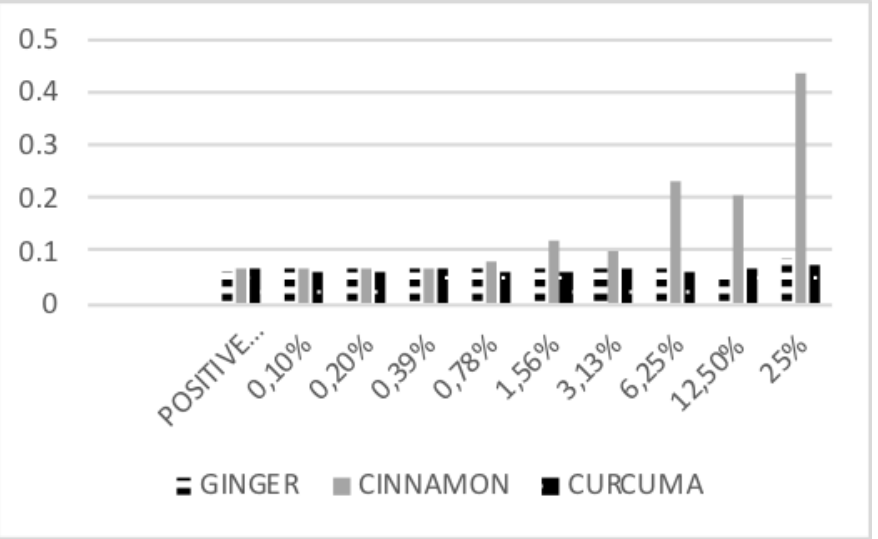

\section{1) Comparison of the Effect of Different Spices on} E.feacalis

E. faecalis in the presence of ginger expressed the highest biofilm forming capacity at the $6,25 \% \mathrm{w} / \mathrm{V}$ solution and the lowest biofilm forming capacity was measured at the $0,195 \%$ w/V solution. In the presence of cinnamon E. feacalis expressed the highest biofilm forming capacity at the $25 \mathrm{w} / \mathrm{V}$ solution and the lowest biofilm forming capacity was measured at the $0,78 \% \mathrm{w} / \mathrm{V}$ solution. E. feacalis in the presence of curcuma expressed the highest biofilm forming capacity at the $0,390 \% \mathrm{w} / \mathrm{V}$ solution and the lowest biofilm forming capacity was measured at the $0,0975 \% \mathrm{w} / \mathrm{V}$ solution.

Fig. 3. Comparison of the Effect of Different Spices on biofilm formation of E.faecalis ATCC 19433

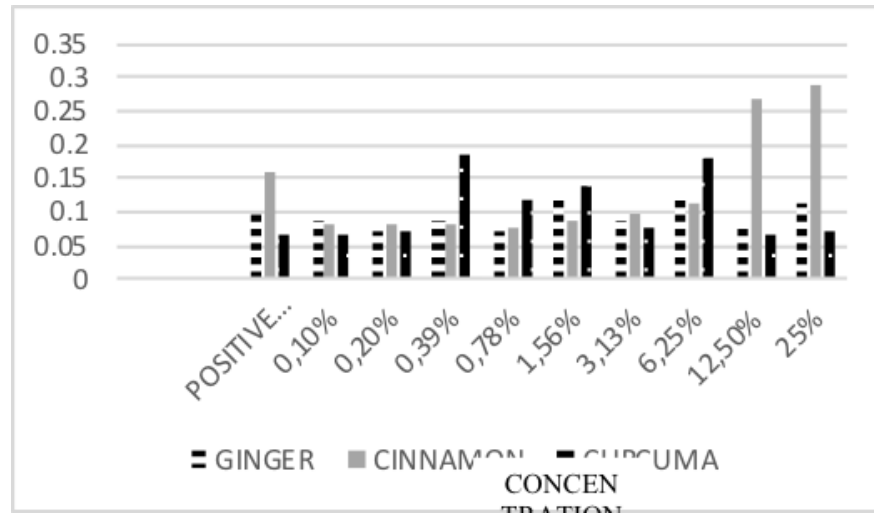

DISCUSSION

Antibiotic resistance worldwide represents a major clinical and public health issue. The misuse and overuse of antibiotics, which have transformed medicine and saved millions of lives, has led to the emergence of resistant bacteria with the propagation of progeny no longer susceptible to them [34-38]. The fact that $99 \%$ have the ability to form biofilms - in which the antibiotic resistance rates are multiple times elevated - only makes this issue more complicated [4]. Another concern is the increasing of antibiotic resistance of pathogens that are the causative agents of food born illnesses [40].

Until now there have been many attempts to find effective and nontoxic antimicrobial and antibiofilm compounds, other than antibiotics, that can be used on a regular basis - as in example in food. A good group of compounds that can respond to all these requirements are herbal spices. Many studies were directed towards testing the antibacterial properties of herbal spices, some also focusing on the antibiofilm forming properties of spices [10-14;18-33] and other substances [34]. However, in small doses molecules within spices can act as signals for quorum sensing in bacteria and affect bacterial biofilm forming capabilities. Considering that spices are multiple times diluted in food - identifying the effect of small doses of commercially available spices on different food pathogens would aid in the adequate choice of spices as well as its dose for food preservation. In our study we tested the antimicrobial effect of different spice (w/v) solutions using agar well method and subsequently serial dilutions of the $25 \%$ w/V solutions of spices were tested for their effect on biofilm formation in 96 well plates. This study showed significant variations in biofilm formation of Staphylococcus aureus, Escherichia coli and Enterococcus faecalis in the presence of different spices and their w/V solution (cinnamon, curcumin and ginger). Results of other studies showed that the effect the tested substances had on biofilm formation in different concentrations was dose dependent [9], which was in accordance with our results.

Namely, biofilm formation of E.coli, where the bacteria expressed no biofilm formation in positive control, in the presence of cinnamon increased and ranged from non adherent at the $3,125 \% \mathrm{w} / \mathrm{V}$ solution to moderate at the $6,25 \% \mathrm{w} / \mathrm{V}$ solution to strong at the $15 \% \mathrm{w} / \mathrm{V}$ solution. Similar results were obtained for Enterococcus faecalis incubated with cinnamon w/V solutions where at the $25 \%$ and $12,5 \% \mathrm{w} / \mathrm{V}$ solution biofilm formation was moderate as opposed to the positive control where no biofilm formation was registered. In the case of Staphylococcus aureus significant changes in the biofilm forming category were registered using different cinnamon $w / V$ solutions (weak biofilm formation at the $0,098 \% \mathrm{w} / \mathrm{V}$ solution and strong biofilm formation at the $6,25 \% \mathrm{w} / \mathrm{V}$ solution and $12,5 \% \mathrm{w} / \mathrm{V}$ solution, as opposed to the positive control which had moderate biofilm formation).

Unlike that in the case of testing biofilm formation of all the tested bacteria in the presence of curcumin, changes in biofilm forming category were registered but they were not as significant as in the case of cinnamon. Curcucmin enhanced biofilm formation in E. faecalis where a change in biofilm forming category was registered (from non adherent in positive control to weak at the $0.39 \%$ w/V solution). For $E$. coli no change in biofilm forming category occurred when comparing positive control and all tested spice concentrations. On the other hand curcumin reduced the biofilm forming capacity of $S$. aureus from moderate (positive control) to weak and non adherent and proved to have antibiofilm forming properties on the tested $S$. aureus strain. The results obtained for curcumin were in accordance with results from another study where curcumin nanoparticles expressed had an antibiofilm forming effect on S.aureus [33].

Similar results were also obtained in the case of ginger. Ginger slightly enhanced biofilm formation in E.faecalis (change in category from non-adherent in positive control to weak to certain spice w/V solutions) and did not have any effect on the biofilm formation of E.coli. Unlike that in the case of $S$. aureus ginger significantly reduced the biofilm forming capacity from moderate to weak and non adherent at higher 
spice w/V solutions. This was in accordance with the results of other studies where ginger expressed significant antibiofilm forming effect on bacteria [20, 21, 22].

The difference on the biofilm forming capability effect of different spices on the tested bacteria, (where certain spices enhanced, certain inhibited while others had no effect on the biofilm formation of tested bacteria) could potentially be explained by the difference in the spice molecular composition. Namely, recent literature even suggests adding small molecules into the central dogma of molecular biology because of the profound effect they have on gene expression [41]. The fact that different genes and gene clusters are responsible for biofilm formation in Escherichia coli, Staphylococcus aureus and Enterococcus faecalis could explain the fact that different spices have different effect on the tested bacteria.

On the other hand, the different effect the same spice has on the biofilm forming capacity of the same bacteria could be explained by the fact that biofilm formation is controlled by quorum sensing and is population density dependent. Since bacteria communicate through a chemical language that is registered by the amount of certain signaling molecules in their surrounding the effect of different spice concentrations could, through quorum sensing, alter collective group behavior including biofilm formation. From this it is apparent that the testing the effect not only of different spices but also their concentration on the biofilm formation of bacteria is crucial for further contribution to the field.

The limitation of our study was the number of the tested bacterial strains, as clinical strains that have a more resistant profile could yield more applicable results compared to the results obtained from referent strains. Statistical analysis was performed in IBM SPSS and values obtained with ANOVA test - which both showed no correlation between the applied spice w/V solution and biofilm formation. This is in accordance with literature findings and supports the hypotheisis that different concentrations of the same substance have a different effect on biofilm formation in bacteria [9].

On the whole, this study has opened a novel frontier and has showed that despite the fact that certain compounds can act as microbicidal substances - once diluted, they can have a profound effect on the expression of genes responsible for biofilm formation. Hence, the finding of novel antimicrobial compounds should be accompanied by biofilm formation studies since biofilms represent the natural state of bacteria and as such must be dealt with.

\section{ACKNOWLEDGMENT}

The preferred spelling of the word "acknowledgment" in America is without an "e" after the "g." Avoid the stilted expression "one of us (R. B. G.) thanks ...". Instead, try "R. B. G. thanks...". Put sponsor acknowledgments in the unnumbered footnote on the first page.

\section{REFERENCES}

[1] Jamal, M., Tasneem, U., Hussain, T., \& Andleeb, S. (2015). Bacterial biofilm: its composition, formation and role in human infections. RRJMB, 4(3), 1-15.

[2] Mah, T. F. C., \& O'toole, G. A. (2001). Mechanisms of biofilm resistance to antimicrobial agents. Trends in microbiology, 9(1), 34-39.

[3] Xu, K. D., McFeters, G. A., \& Stewart, P. S. (2000). Biofilm resistance to antimicrobial agents. Microbiology, 146(3), 547-549.
[4] Høiby, N., Bjarnsholt, T., Givskov, M., Molin, S., \& Ciofu, O. (2010). Antibiotic resistance of bacterial biofilms. International journal of antimicrobial agents, 35(4), 322-332.

[5] Hood, S.K., Zottola,E.A, (1995): Biofilms In Food Processing. Food Control 6: 9-18

[6] Hoffman, L. R., D'argenio, D. A., MacCoss, M. J., Zhang, Z., Jones, R. A., \& Miller, S. I. (2005). Aminoglycoside antibiotics induce bacterial biofilm formation. Nature, 436(7054), 1171.

[7] Bagge, N., Schuster, M., Hentzer, M., Ciofu, O., Givskov, M., Greenberg, E. P., \& Høiby, N. (2004). Pseudomonas aeruginosa biofilms exposed to imipenem exhibit changes in global gene expression and $\beta$ lactamase and alginate production. Antimicrobial agents and chemotherapy, 48(4), 1175-1187.

[8] Kaplan, J. B. (2011). Antibiotic-induced biofilm formation. The International journal of artificial organs, 34(9), 737-751.

[9] Rachid, S., Ohlsen, K., Witte, W., Hacker, J., \& Ziebuhr, W. (2000). Effect of subinhibitory antibiotic concentrations on polysaccharide intercellular adhesin expression in biofilm-forming Staphylococcus epidermidis. Antimicrobial agents and chemotherapy, 44(12), 33573363.

[10] Bazargani, M. M., \& Rohloff, J. (2016). Antibiofilm activity of essential oils and plant extracts against Staphylococcus aureus and Escherichia coli biofilms. Food Control, 61, 156-164.

[11] Różalski, M., Walencka, E., Różalska, B., \& Wysokińska, H. (2007). Antimicrobial activity of diterpenoids from hairy roots of Salvia sclarea L.: Salvipisone as a potential anti-biofilm agent active against antibiotic resistant Staphylococci. Phytomedicine, 14(1), 31-35.

[12] Quave, C. L., Plano, L. R., Pantuso, T., \& Bennett, B. C. (2008). Effects of extracts from Italian medicinal plants on planktonic growth, biofilm formation and adherence of methicillin-resistant Staphylococcus aureus. Journal of ethnopharmacology, 118(3), 418-428.

[13] Sandasi, M., Leonard, C. M., \& Viljoen, A. M. (2010). The in vitro antibiofilm activity of selected culinary herbs and medicinal plants against Listeria monocytogenes. Letters in applied microbiology, 50(1), 30-35.

[14] Brackman, G., \& Coenye, T. (2015). Quorum sensing inhibitors as antibiofilm agents. Current pharmaceutical design, 21(1), 5-11.

[15] Shi, X., \& Zhu, X. (2009). Biofilm formation and food safety in food industries. Trends in Food Science \& Technology, 20(9), 407-413.

[16] Srey, S., Jahid, I. K., \& Ha, S. D. (2013). Biofilm formation in food industries: a food safety concern. Food control, 31(2), 572-585.

[17] Jahid, I. K., \& Ha, S. D. (2012). A review of microbial biofilms of produce: future challenge to food safety. Food Science and Biotechnology, 21(2), 299-316.

[18] Nanasombat, S. (2005). Antibacterial activity of crude ethanolic extracts and essential orls of spices against salmonelae and other enterobacteria. Current applied sclence and technology, 5(3).

[19] Yassen, D., \& Ibrahim, A. E. (2016). Antibacterial activity of crude extracts of ginger (Zingiber officinale Roscoe) on Escherichia coli and Staphylococcus aureus: A Study in vitro. Indo American Journal of Pharmaceutical Research, 6(06), 5830-35.

[20] Nikolić, M., Vasić, S., Đurđević, J., Stefanović, O., \& Čomić, L. (2014) Antibacterial and anti-biofilm activity of ginger (Zingiber officinale (Roscoe)) ethanolic extract. Kragujevac Journal of Science, (36), 129136.

[21] Aghazadeh, M., Bialvaei, A. Z., Aghazadeh, M., Kabiri, F., Saliani, N., Yousefi, M., ... \& Kafil, H. S. (2016). Survey of the antibiofilm and antimicrobial effects of Zingiber officinale (in vitro study). Jundishapur journal of microbiology, 9(2).

[22] Khiralla, G. M. (2015). Antibiofilm and anti-adhesive effects of ginger against some food-related pathogens. J Food Res Technol, 3, 87-96.

[23] Kim, Y. G., Lee, J. H., Kim, S. I., Baek, K. H., \& Lee, J. (2015). Cinnamon bark oil and its components inhibit biofilm formation and toxin production. International journal of food microbiology, 195, 30-39.

[24] Cui, H., Li, W., Li, C., Vittayapadung, S., \& Lin, L. (2016). Liposome containing cinnamon oil with antibacterial activity against methicillinresistant Staphylococcus aureus biofilm. Biofouling, 32(2), 215-225.

[25] Almeida, L. D. F. D. D., Paula, J. F. D., Almeida, R. V. D. D., Williams, D. W., Hebling, J., \& Cavalcanti, Y. W. (2016). Efficacy of citronella and cinnamon essential oils on Candida albicans biofilms. Acta Odontologica Scandinavica, 74(5), 393-398. 
[26] Kalia, M., Yadav, V. K., Singh, P. K., Sharma, D., Pandey, H., Narvi, S. S., \& Agarwal, V. (2015). Effect of cinnamon oil on quorum sensingcontrolled virulence factors and biofilm formation in Pseudomonas aeruginosa. PLoS one, 10(8), e0135495.

[27] Nabavi, S. F., Di Lorenzo, A., Izadi, M., Sobarzo-Sánchez, E., Daglia, M., \& Nabavi, S. M. (2015). Antibacterial effects of cinnamon: From farm to food, cosmetic and pharmaceutical industries. Nutrients, 7(9), 7729-7748.

[28] Mukhtar, S., \& Ghori, I. (2012). Antibacterial activity of aqueous and ethanolic extracts of garlic, cinnamon and turmeric against Escherichia coli ATCC 25922 and Bacillus subtilis DSM 3256. International Journal of applied biology and pharmaceutical Technology, 3(2), 131-136.

[29] Teow, S. Y., Liew, K., Ali, S. A., Khoo, A. S. B., \& Peh, S. C. (2016). Antibacterial action of curcumin against Staphylococcus aureus: a brief review. Journal of tropical medicine, 2016.

[30] Packiavathy, I. A. S. V., Agilandeswari, P., Musthafa, K. S., Pandian, S. K., \& Ravi, A. V. (2012). Antibiofilm and quorum sensing inhibitory potential of Cuminum cyminum and its secondary metabolite methyl eugenol against Gram negative bacterial pathogens. Food Research International, 45(1), 85-92

[31] Gunes, H., Gulen, D., Mutlu, R., Gumus, A., Tas, T., \& Topkaya, A. E. (2016). Antibacterial effects of curcumin: an in vitro minimum inhibitory concentration study. Toxicology and industrial health, 32(2), 246-250.

[32] Derakhshan, S., Navidinia, M., \& Ahmadi, A. (2017). Antibacterial Activity of Dill (Anethum graveolens) Essential Oil and Antibiofilm Activity of Cumin (Cuminum cyminum) Alcoholic Extract. Infection, Epidemiology and Microbiology, 3(4), 122-126.
[33] Loo, C. Y., Rohanizadeh, R., Young, P. M., Traini, D., Cavaliere, R., Whitchurch, C. B., \& Lee, W. H. (2015). Combination of silver nanoparticles and curcumin nanoparticles for enhanced anti-biofilm activities. Journal of agricultural and food chemistry, 64(12), 25132522.

[34] Hukić, M., Seljmo, D., Ramovic, A., Ibrišimović, M. A., Dogan, S., Hukic, J., \& Bojic, E. F. (2018). The Effect of Lysozyme on Reducing Biofilms by Staphylococcus aureus, Pseudomonas aeruginosa, and Gardnerella vaginalis: An In Vitro Examination. Microbial Drug Resistance, 24(4), 353-358.

[35] Golkar Z, Bagazra O, Pace DG. Bacteriophage therapy: a potential solution for the antibiotic resistance crisis. J Infect Dev Ctries. 2014;8(2):129-136. 13.

[36] Gould IM, Bal AM. New antibiotic agents in the pipeline and how they can overcome microbial resistance. Virulence. 2013;4(2):185-191.

[37] Wright GD. Something new: revisiting natural products in antibiotic drug discovery. Can J Microbiol. 2014;60(3):147-154.

[38] Sengupta S, Chattopadhyay MK, Grossart HP. The multifaceted roles of antibiotics and antibiotic resistance in nature. Front Microbiol. 2013;4:47.

[39] Levy, S. B. (2002). Factors impacting on the problem of antibiotic resistance. Journal of Antimicrobial Chemotherapy, 49(1), 25-30.

[40] Shan, B., Cai, Y. Z., Brooks, J. D., \& Corke, H. (2007). The in vitro antibacterial activity of dietary spice and medicinal herb extracts. International Journal of food microbiology, 117(1), 112-119

[41] Schneider-Poetsch, T., \& Yoshida, M. (2018). Along the Central Dogma - Controlling Gene Expression with Small Molecules. Annual review of biochemistry. 